\title{
Live animal and carcass characteristics of South African indigenous goats
}

\author{
L. Simela ${ }^{1 \#}$, E.C. Webb ${ }^{2}$, M.J.C. Bosman ${ }^{3}$ \\ ${ }^{1}$ National Emergent Red Meat Producers' Organisation, P.O. Box 36461, Menlo Park, Pretoria 0102, South Africa \\ ${ }^{2}$ Department of Animal and Wildlife Sciences, University of Pretoria, Hatfield, Pretoria 0002, South Africa \\ ${ }^{3}$ School for Physiology, Nutrition and Consumer Sciences, North-West University, Private Bag X6001, \\ Potchefstroom 2520, South Africa
}

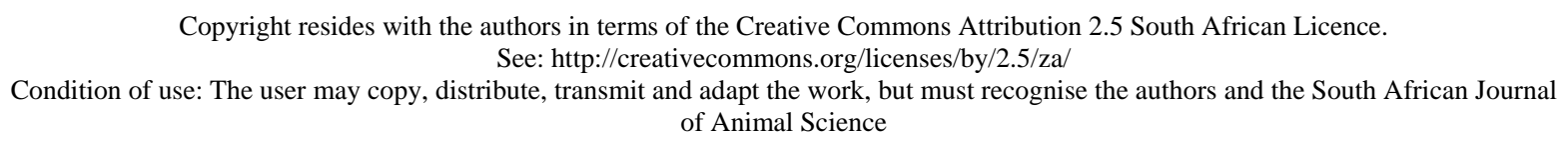

\begin{abstract}
Eighty-nine intact male, castrates and female South African indigenous goats in three age groups $(0$, 2 - 6 and 8 permanent incisors) and two pre-slaughter conditioning groups; namely, the non-conditioned which were slaughtered within three months of purchase and the pre-slaughter conditioned, which were slaughtered 6 - 10 months after purchase or birth were used. The effect of sex, age and pre-slaughter conditioning on live animal, carcass dimensions and carcass composition were evaluated. The goats were large with live weight, carcass weight and carcass dimensions in the range of the large breeds of southern Africa. They had a high lean and low fat content. Intact males were suited for high chevon yield because they were heavy, had a high lean and low fat content, and losses during dressing and chilling were reduced by improved nutrition. Goats between 2 - 6 teeth yielded heavy carcasses that were comparable to goats in the 8-teeth group, and had proportionately more lean and less carcass fat. The hind limb was ideal for high lean and low fat, high value cuts but the dorsal trunk was bony and yielded less lean. Pre-slaughter conditioning improved the overall size of the goats and reduced the losses during slaughter and chilling. It also improved the lean/bone and lean and fat/bone indices.
\end{abstract}

Keywords: Live weight, chest girth, dressing out percentage, carcass composition

\# Corresponding author: langa@nerpo.org.za

\section{Introduction}

The acceptability of a carcass lies in its perceived value, which includes the potential meat yield of the carcass and the eating quality of the meat (Chrystall, 1998). To processors, wholesalers and the producers to some extent, the value of the carcass lies mainly in its potential saleable meat yield (Chrystall, 1998). Traits such as the weight and conformation of the live animal and of the carcass as well as fat distribution within the carcass are therefore of great importance in meat production. The proportion of high value cuts is also an important indication of the overall value of the carcass. Live animal and carcass attributes are principally concerned with the quantity of saleable meat that can be obtained from the carcass but also have significant implications on the technological properties such as $\mathrm{pH}$, colour and tenderness.

There is a lack of information on the characteristics of indigenous goat breeds of Africa and hence efforts to compile databases on these breeds have been ineffective (Simela \& Merkel, 2008). Thus, the purpose of this paper is to describe live animal and carcass quality of South African indigenous goats in relation to meat production potential. It provides essential baseline information that can be used in breed selection of meat goats.

\section{Materials and Methods}

In total 89 goats distributed by age (based on dentition), sex and pre-slaughter conditioning as shown in Table 1 were slaughtered. The flock ranged from recently weaned kids to 6-teeth castrates and intact males and 8-teeth females. The goats were kept at the Hatfield Experimental Farm, University of Pretoria prior to slaughter. On arrival at the farm, the goats were vaccinated against pulpy kidney and pasteurellosis, and were 
dosed against major internal parasites. They were separated into males and females in two adjacent pens, raised and slaughtered as described by Simela et al. (2004).

The majority of the young goats, especially the females, were purchased at about 13 - $15 \mathrm{~kg}$ and hence for this study, they were raised to at least $25 \mathrm{~kg}$ before slaughter. Consequently most of the 2-teeth goats were slaughtered in the pre-conditioned state.

Table 1 Distribution of experimental goats by age (dentition) class, sex and pre-slaughter conditioning

\begin{tabular}{clrrrr}
\hline Age class (dentition) $^{*}$ & Pre-slaughter conditioning & Castrates & Female & Intact males & Total \\
\hline \multirow{2}{*}{ 0-teeth } & Non-conditioned & 6 & 1 & 3 & 10 \\
& Conditioned & & 3 & 4 & 7 \\
2-teeth & Non-conditioned & 7 & & 1 & 8 \\
4-6 teeth & Conditioned & 7 & 13 & 4 & 24 \\
8-teeth & Non-conditioned & 9 & 7 & 4 & 20 \\
& Non-conditioned & & 11 & 11 \\
Total & Conditioned & & 9 & 9 \\
Grand total & Non-conditioned & 22 & 19 & 8 & 49 \\
& Conditioned & 7 & 25 & 40
\end{tabular}

*NB: Incisors were considered in pairs. Thus if one of the first pair of incisors had erupted then the goat was considered 2-teeth; if one of the second pair had erupted then the goat was taken as 4-teeth, etc.

\#Non-conditioned - slaughtered within three months of purchase; Conditioned - slaughtered between six and 10 months of purchase or birth.

After skinning and evisceration, omental fat was removed from the viscera of each goat and weighed separately. Hot carcass weight (HCW) was measured prior to washing and chilling. The carcasses were chilled at $2-4{ }^{\circ} \mathrm{C}$ for $23 \mathrm{~h}$. Thereafter they were weighed to obtain cold carcass weight (CCW). All the kidney knob and channel fat (KKCF) and the kidneys were then removed. The KKCF was weighed, vacuumpacked and stored at $-20^{\circ} \mathrm{C}$. The carcass was split in half along the dorso-ventral plane. The right side was weighed and carcass side lengths were measured as prescribed by Fisher \& de Boer (1994). Thereafter the side was jointed into neck, fore limb, ventral trunk, dorsal trunk and hind limb (Casey, 1982). The dorsal trunk was further split between the $12^{\text {th }}$ and $13^{\text {th }}$ ribs and the area of the $m$. longissimus thoracis (LT) on the surface of the $12^{\text {th }}$ rib (LT area) was traced out. The area of this muscle was later measured from the tracing using a visual image analyser (VIA, Kontron, Germany).

Each joint was dissected into the separable tissues; lean, bone, intermuscular and subcutaneous fat as defined by Fisher \& de Boer (1994). Each tissue was weighed separately for each joint. The weights and fat of the $m$. semimembranosus and $m$. longissimus thoracis that were removed for other evaluations (Simela et al., 2004) were added to the weights of the hind limb and dorsal trunk, respectively.

Dressing out percentage and chilling losses were calculated as follows:

Dressing out $(\%)=\frac{C C W}{\text { Liveweight }} \times 100 \quad$ Chilling losses (\%) $=\frac{H C W-C C W}{H C W} \times 100$

Other variables that were calculated were the proportions of the dissectible tissues within the joints and within the right half carcass, the yield indices lean/bone and lean-and-fat/bone as well as the proportions of the joints within the side.

General linear model (GLM) procedures of SAS (1996) were used to test the effects of sex, age classes and pre-slaughter conditioning and first order interaction effects on live animal and carcass characteristics. 
Pre-analysis tests were carried out for each of the variables. Where the data for a variable were not normally distributed, the rank transformation was performed and the transformed variable was used in the GLM analysis. For first order interaction effects of sex were nested in age and age nested in pre-slaughter conditioning since not all sexes occurred in all age groups and not all age groups were represented in both pre-slaughter conditioning groups (Table 1$)$. Where F-tests were significant $(P<0.05)$, Scheffé's test was used to compare means. In some cases there was only one animal (Table 1) in the group but the data were analysed as they were.

\section{Results}

The effects of sex, age and pre-slaughter conditioning on live animal and carcass characteristics are presented in Tables 2, 3 and 4.

Male goats were significantly bigger $(P<0.0001)$ than the females (Table 2$)$. On average, intact and castrated males were $5.4 \mathrm{~kg}$ heavier at slaughter and the chilled carcasses were $2.3 \mathrm{~kg}$ heavier than those of the females. Mean losses during dressing and chilling did not vary with sex $(P>0.05)$. The overall mean dressing out percentage and chilling losses were respectively $40.5 \pm 4.41 \%$ and $2.7 \pm 1.03 \%$. Intact males had the largest frames, reflected by the broader mean chest girth $(P<0.01)$. There was almost twice as much omental fat and KKCF in female than in male goats $(P<0.05)$ but the LT area (mean $\left.=11.7 \pm 3.44 \mathrm{~cm}^{2}\right)$ did not differ significantly between the sexes $(P>0.05)$.

Table 2 Effect of sex on live animal and carcass characteristics of South African indigenous goats (means \pm S.D.)

\begin{tabular}{|c|c|c|c|c|}
\hline & \multicolumn{3}{|c|}{ Sex } & \multirow{2}{*}{$P$-value } \\
\hline & Castrates & Females & Intact males & \\
\hline $\mathrm{N}$ & 29 & 44 & 15 & \\
\hline Slaughter weight (kg) & $36.0^{\mathrm{b}} \pm 6.47$ & $31.4^{\mathrm{a}} \pm 5.87$ & $37.7^{\mathrm{b}} \pm 7.17$ & $<0.0001$ \\
\hline Cold carcass weight (kg) & $14.7^{\mathrm{b}} \pm 3.55$ & $12.9^{\mathrm{a}} \pm 2.84$ & $15.5^{\mathrm{b}} \pm 3.88$ & 0.0021 \\
\hline Chest girth (cm) & $78.2^{\mathrm{b}} \pm 5.99$ & $74.8^{\mathrm{a}} \pm 5.21$ & $79.5 \pm 6.82$ & 0.0032 \\
\hline Side length (cm) & $63.7 \pm 4.31$ & $62.5 \pm 4.10$ & $64.3 \pm 2.30$ & 0.1956 \\
\hline M. longissimus thoracis area $\left(\mathrm{cm}^{2}\right)$ & $12.2 \pm 3.05$ & $11.1 \pm 3.19$ & $12.4 \pm 4.57$ & 0.2118 \\
\hline Dressing out percentage & $40.8 \pm 3.66$ & $41.0 \pm 4.46$ & $40.9 \pm 5.50$ & 0.9772 \\
\hline Chilling losses (percentage) & $2.2 \pm 0.89$ & $2.7 \pm 1.06$ & $2.6 \pm 1.26$ & 0.0979 \\
\hline Omental fat $\%^{\dagger}$ & $1.3^{\mathrm{a}} \pm 0.98$ & $2.4^{\mathrm{b}} \pm 1.66$ & $1.20^{\mathrm{a}} \pm 1.14$ & 0.0470 \\
\hline Kidney knob and channel fat $\%^{\ddagger}$ & $2.1^{\mathrm{a}} \pm 1.35$ & $3.9^{b} \pm 2.03$ & $2.2^{\mathrm{a}} \pm 1.46$ & 0.0070 \\
\hline
\end{tabular}

† Omental fat is expressed as percent slaughter weight; $\ddagger$ Kidney knob and channel fat is expressed as percent cold carcass weight.

Means in the same row with different superscripts 'a' or 'b' differ significantly $(P<0.05)$.

All mean weight and linear measurements increased significantly $(P<0.01)$ with animal age, as was expected (Table 3). The overall increases in mean live and carcass weights were $53 \%$ and $43 \%$, respectively, between the milk- and 8-teeth groups. Corresponding increases in mean chest girth and side length were $18 \%$ and $15 \%$, respectively. $M$. longissimus thoracis area did not vary $(P>0.05)$ with the age of the goats, neither did the dressing out percentage though there was a tendency for the values to decrease with age $(P=0.087)$. Chilling losses were highest for the 2-teeth group $(P<0.05)$ but similar across all other age groups. Since the 4 - 6 teeth group was slaughtered within the non-conditioned group only, it had the lowest omental fat content; which was significantly different from that of the 8-teeth group $(P<0.05)$.

The goats that were conditioned prior to slaughter were bigger than the non-conditioned group (Table 4). On average the conditioned group was $4 \mathrm{~kg}$ heavier $(P=0.0004)$ and their carcasses were $3.6 \mathrm{~kg}$ heavier $(P=0.0001)$ than those of the non-conditioned goats. The carcasses of the pre-slaughter conditioned 
goats lost less weight during dressing (5.8\%) and chilling (0.93\%) compared to those of the non-conditioned group $(P<0.0001)$.

Table 3 Effect of age on live animal and carcass characteristics of South African indigenous goats (means \pm S.D.)

\begin{tabular}{|c|c|c|c|c|c|}
\hline & \multicolumn{4}{|c|}{ Age class } & \multirow{2}{*}{$P$-value } \\
\hline & 0 -teeth & 2-teeth & 4- to 6-teeth & 8-teeth & \\
\hline $\mathrm{N}$ & 16 & 32 & 20 & 20 & \\
\hline Slaughter weight (kg) & $27.8^{\mathrm{a}} \pm 3.8$ & $33.1^{\mathrm{b}} \pm 5.66$ & $36.6^{c} \pm 6.39$ & $42.7^{\mathrm{d}} \pm 3.92$ & $<0.0001$ \\
\hline Cold carcass weight (kg) & $11.8^{\mathrm{a}} \pm 2.43$ & $13.7^{\mathrm{b}} \pm 3.18$ & $15.2^{\mathrm{bc}} \pm 3.10$ & $16.9^{c} \pm 2.88$ & $<0.0001$ \\
\hline Chest girth (cm) & $71.1^{\mathrm{a}} \pm 3.44$ & $75.5^{\mathrm{b}} \pm 4.74$ & $79.3^{c} \pm 6.89$ & $84.1^{\mathrm{d}} \pm 2.39$ & $<0.0001$ \\
\hline Side length (cm) & $59.7^{\mathrm{a}} \pm 2.48$ & $62.0^{\mathrm{b}} \pm 3.31$ & $63.6^{\mathrm{b}} \pm 3.72$ & $68.7^{\mathrm{c}} \pm 2.43$ & $<0.0001$ \\
\hline M. longissimus thoracis area $\left(\mathrm{cm}^{2}\right)$ & $11.1 \pm 3.94$ & $11.1 \pm 3.35$ & $12.5 \pm 2.30$ & $12.9 \pm 3.07$ & 0.3345 \\
\hline Dressing out percentage & $42.2 \pm 5.99$ & $41.0 \pm 3.36$ & $41.4 \pm 2.90$ & $39.0 \pm 4.34$ & 0.0868 \\
\hline Chilling losses ( percentage) & $2.2^{\mathrm{a}} \pm 1.38$ & $3.0 \mathrm{~b} \pm 0.56$ & $2.4^{\mathrm{a}} \pm 1.06$ & $2.3^{\mathrm{a}} \pm 1.23$ & 0.0250 \\
\hline Omental fat $\%^{\dagger}$ & $1.6^{\mathrm{ab}} \pm 1.33$ & $2.3^{\mathrm{ab}} \pm 1.15$ & $0.6^{\mathrm{a}} \pm 0.56$ & $2.5^{\mathrm{b}} \pm 1.92$ & 0.0210 \\
\hline Kidney knob and channel fat $\%^{\ddagger}$ & $2.6 \pm 2.18$ & $3.4 \pm 1.65$ & $1.8 \pm 0.87$ & $3.0 \pm 1.94$ & 0.0660 \\
\hline
\end{tabular}

$\dagger$ Omental fat is expressed as percent slaughter weight; $\ddagger$ Kidney knob and channel fat is expressed as percent cold carcass weight.

Means in the same row with different superscripts 'a', 'b', 'c' or 'd' differ significantly $(P<0.05)$.

Table 4 Effect of pre-slaughter conditioning on live animal and carcass characteristics of South African indigenous goats (means \pm S.D.)

\begin{tabular}{lccc}
\hline & \multicolumn{2}{c}{ Pre-slaughter conditioning } & \\
\cline { 2 - 3 } & $\begin{array}{c}\text { Non- } \\
\text { conditioned }\end{array}$ & Conditioned & P- value \\
\hline $\mathrm{N}$ & 49 & 39 & \\
Slaughter weight (kg) & $31.9 \pm 6.08$ & $35.9 \pm 5.86$ & 0.0004 \\
Cold carcass weight (kg) & $12.1 \pm 2.81$ & $15.7 \pm 2.66$ & $<0.0001$ \\
Chest girth (cm) & $75.5 \pm 6.08$ & $77.6 \pm 5.13$ & 0.0088 \\
Side length (cm) & $62.3 \pm 4.44$ & $63.9 \pm 3.40$ & 0.0280 \\
M. longissimus thoracis area (cm2) & $9.0 \pm 2.32$ & $13.8 \pm 2.83$ & $<0.0001$ \\
Dressing out percentage & $37.9 \pm 3.61$ & $43.9 \pm 2.78$ & $<0.0001$ \\
Chilling losses (percentage) & $3.1 \pm 1.05$ & $2.2 \pm 0.73$ & $<0.0001$ \\
Omental fat \% ${ }^{\dagger}$ & $0.8 \pm 0.72$ & $1.8 \pm 1.49$ & $<0.0001$ \\
${\text { Kidney knob and channel fat } \%^{\ddagger}}$ & $1.7 \pm 0.94$ & $4.7 \pm 1.52$ & $<0.0001$ \\
\hline
\end{tabular}

$\dagger$ Omental fat is expressed as percent slaughter weight;

‡ Kidney knob and channel fat is expressed as percent cold carcass weight.

Pre-slaughter conditioned goats also had the bigger frames reflected in the larger chests and carcass side lengths $(P<0.05)$. The LT area, omental fat and KKCF values for the pre-slaughter conditioned group were, respectively, 54\%, 235\% and 278\% greater than the values of the non-conditioned group. In summary, 
pre-slaughter conditioning increased the overall size of the goats and the fat content, and resulted in reduced losses during dressing and chilling.

There were significant interaction effects of sex and pre-slaughter conditioning on dressing percentage and chilling losses (Figure 1).
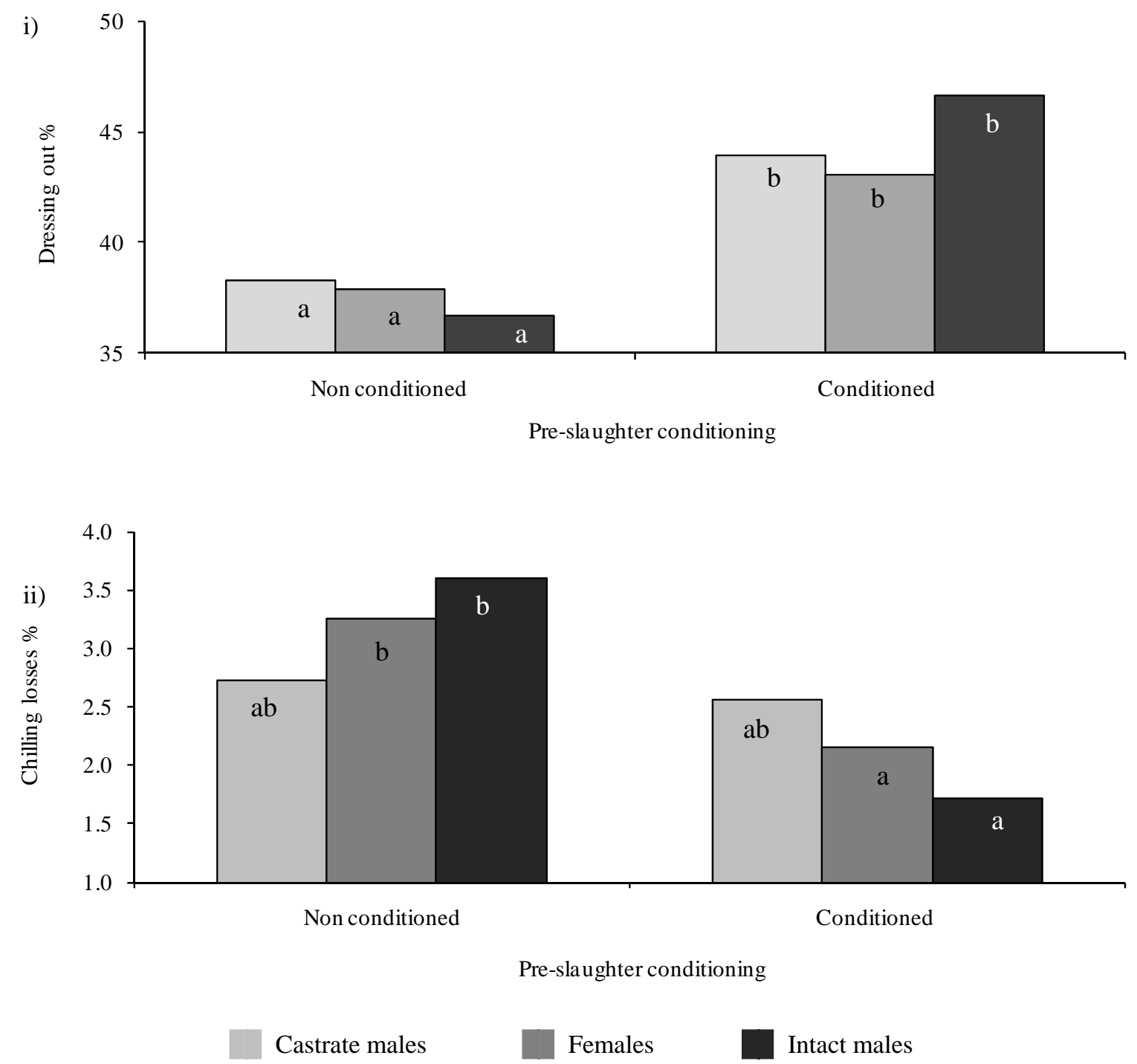

Bars within a graph with different letters 'a' or 'b' differ significantly $(P<0.05)$

Figure 1 The interaction effects between pre-slaughter conditioning and sex on i) dressing out percentages and ii) chilling losses percentages.

Dressing out percentages of the pre-slaughter conditioned goats were higher than for the nonconditioned goats $(P<0.05)$, more so for the intact males than for the castrates and females (Figure 1i). However, values within each pre-slaughter conditioning group did not differ significantly $(P>0.05)$. Conversely, chilling losses from the carcasses of the conditioned females and intact males were significantly lower $(P<0.05)$ than those of the non-conditioned ones (Figure 1ii). Chilling losses from the carcasses of the castrates were not significantly affected by pre-slaughter conditioning $(P>0.05)$.

In terms of joint proportions within the carcass, the major differences among the three sex groups were that the intact males had proportionally heavier necks $(P<0.0001)$ and smaller hindquarters $(P<0.01)$ than the castrates and females (Table 5). The proportions of fore limb, ventral trunk and dorsal trunk did not differ significantly among the females, castrates and intact males $(P>0.05)$. 
Table 5 Effect of sex on joint proportions (\%) in the right carcass halves of South African indigenous goats (means \pm S.D.)

\begin{tabular}{lcccc}
\hline \multirow{2}{*}{ Characteristic } & \multicolumn{3}{c}{ Sex } & \multirow{2}{*}{$P$-value } \\
\cline { 2 - 4 } & Castrates & Females & Intact males & \\
\hline $\mathrm{N}$ & 29 & 44 & 15 & \\
Neck & $11.7^{\mathrm{a}} \pm 1.33$ & $11.7^{\mathrm{a}} \pm 1.24$ & $14.0^{\mathrm{b}} \pm 1.79$ & 0.0001 \\
Fore limb & $19.1 \pm 1.03$ & $18.9 \pm 1.39$ & $18.7 \pm 1.69$ & 0.6438 \\
Dorsal trunk & $20.3 \pm 1.56$ & $21.0 \pm 1.59$ & $20.8 \pm 1.06$ & 0.2809 \\
Ventral trunk & $19.0 \pm 2.02$ & $18.7 \pm 2.49$ & $18.2 \pm 2.66$ & 0.4408 \\
Hind limb & $29.9^{\mathrm{b}} \pm 1.46$ & $29.8^{\mathrm{b}} \pm 1.87$ & $28.3^{\mathrm{a}} \pm 2.14$ & 0.0048 \\
\hline
\end{tabular}

Means in the same row with different superscripts 'a'or 'b' differ significantly $(P<0.05)$.

Intact male carcasses were leaner and hence had a higher lean content and less fat in the intermuscular and subcutaneous depots than the females and castrated males (Table 6). The latter two had similar fat and lean content. The proportion of bone in the carcass was not significantly affected by the sex of the goats $(P>0.05)$. The indices, lean/bone and lean-and-fat/bone, were not affected $(P>0.05)$ by the sex of the goats. The overall means were $3.0 \pm 0.38$ lean/bone and $3.7 \pm 0.68$ lean-and-fat/bone ratios.

Table 6 Effect of sex on proportions of the dissectible tissues (\%) and meat yield indices of the right carcass halves of South African indigenous goats (means \pm S.D.)

\begin{tabular}{lrrrc}
\hline \multirow{2}{*}{ Characteristic } & \multicolumn{3}{c}{ Sex } & \multirow{2}{*}{$P$-value } \\
\cline { 2 - 4 } & \multicolumn{1}{c}{ Castrates } & Females & Intact males & \\
\hline $\mathrm{N}$ & 29 & 44 & 15 & \\
Lean & $62.1^{\mathrm{a}} \pm 2.96$ & $61.4^{\mathrm{a}} \pm 4.92$ & $66.0^{\mathrm{b}} \pm 2.66$ & $<0.0001$ \\
Bone & $20.9 \pm 2.60$ & $21.5 \pm 3.36$ & $22.2 \pm 3.79$ & 0.2837 \\
Intermuscular fat & $11.0^{\mathrm{b}} \pm 2.85$ & $11.2^{\mathrm{b}} \pm 5.23$ & $8.1^{\mathrm{a}} \pm 4.46$ & 0.0037 \\
Subcutaneous fat & $5.1^{\mathrm{b}} \pm 2.25$ & $5.2^{\mathrm{b}} \pm 2.07$ & $2.7^{\mathrm{a}} \pm 1.53$ & $<0.0001$ \\
Total carcass fat & $16.1^{\mathrm{b}} \pm 4.63$ & $16.4^{\mathrm{b}} \pm 6.85$ & $10.8^{\mathrm{a}} \pm 5.20$ & $<0.0001$ \\
Lean/bone & $3.0 \pm 0.31$ & $2.9 \pm 0.41$ & $3.1 \pm 0.44$ & 0.4767 \\
Lean-and-fat/bone & $3.9 \pm 0.52$ & $3.7 \pm 0.73$ & $3.6 \pm 0.70$ & 0.7209 \\
\hline
\end{tabular}

Means in the same row with different superscripts ‘a' or 'b’ differ significantly $(P<0.05)$.

Within joints, intact males had the highest lean content $(P<0.05)$ and least intermuscular (except in the ventral trunk) and subcutaneous fat $(P<0.05)$ (Table 7). Castrates and female goats had similar proportions of lean, intermuscular and subcutaneous (except in hind limb) fat. The proportion of bone in each joint (except the hind limb) was similar amongst the three sex groups $(P>0.05)$. Intermuscular fat in the ventral trunk did not vary $(P>0.05)$ with the sex of the goats. The hind limb bone percentage of intact males was a significant $2 \%$ units greater than that of the females $(P<0.05)$. Subcutaneous fat on the hind limb was most variable, and significantly differed amongst the three sex groups $(P<0.0001)$.

Percentages of the neck, fore limb and dorsal trunk were similar amongst $(P>0.05)$ the goats in the different age groups (Table 8). Percentage of the ventral trunk was lowest in the 2-teeth group and conversely that of the hind limb was highest in the same group $(P<0.01)$. The rest of the age classes had similar proportions of the two joints. 
Table 7 Effect of sex on proportions of the dissectible tissues (\%) within joints of the right carcass halves of South African indigenous goats (means \pm S.D.)

\begin{tabular}{|c|c|c|c|c|}
\hline & \multicolumn{3}{|c|}{ Sex } & \multirow{2}{*}{$P$-value } \\
\hline & Females & Castrates & Intact males & \\
\hline $\mathrm{N}$ & 44 & 29 & 15 & \\
\hline Lean : Neck & $56.1^{\mathrm{a}} \pm 6.74$ & $60.8^{\mathrm{a}} \pm 5.13$ & $67.1^{\mathrm{b}} \pm 4.04$ & $<0.0001$ \\
\hline Fore limb & $64.6^{\mathrm{a}} \pm 4.29$ & $64.2^{\mathrm{a}} \pm 1.94$ & $68.4^{\mathrm{b}} \pm 3.86$ & 0.0002 \\
\hline Dorsal trunk & $56.2^{\mathrm{a}} \pm 6.47$ & $57.2^{\mathrm{a}} \pm 3.62$ & $60.8^{\mathrm{b}} \pm 4.22$ & 0.0075 \\
\hline Ventral trunk & $55.5^{\mathrm{a}} \pm 7.55$ & $57.2^{\mathrm{a}} \pm 8.21$ & $61.6^{\mathrm{b}} \pm 5.64$ & 0.0038 \\
\hline Hind limb & $69.0^{\mathrm{ab}} \pm 3.77$ & $68.2^{\mathrm{a}} \pm 2.26$ & $70.8^{\mathrm{b}} \pm 2.80$ & 0.0373 \\
\hline Bone : Neck & $23.0 \pm 4.96$ & $20.5 \pm 4.36$ & $20.5 \pm 4.87$ & 0.0800 \\
\hline Fore limb & $21.7 \pm 3.23$ & $22.1 \pm 3.10$ & $23.3 \pm 3.24$ & 0.2442 \\
\hline Dorsal trunk & $26.8 \pm 5.00$ & $26.4 \pm 5.23$ & $27.6 \pm 5.32$ & 0.6973 \\
\hline Ventral trunk & $15.8 \pm 4.92$ & $15.7 \pm 2.96$ & $17.4 \pm 6.00$ & 0.4227 \\
\hline Hind limb & $20.6^{\mathrm{ab}} \pm 2.46$ & $19.9^{\mathrm{a}} \pm 2.34$ & $21.9^{\mathrm{b}} \pm 2.63$ & 0.0172 \\
\hline Intermuscular fat : Neck & $14.6^{\mathrm{b}} \pm 7.93$ & $14.3^{\mathrm{b}} \pm 4.41$ & $10.7^{\mathrm{a}} \pm 6.04$ & 0.0174 \\
\hline Fore limb & $9.3 b \pm 5.85$ & $8.9^{b} \pm 3.25$ & $5.0^{\mathrm{a}} \pm 3.59$ & 0.0049 \\
\hline Dorsal trunk & $10.5 \pm 6.29$ & $10.3^{\mathrm{b}} \pm 3.71$ & $6.7^{\mathrm{a}} \pm 4.41$ & 0.0106 \\
\hline Ventral trunk & $19.2 \pm 9.35$ & $17.9 \pm 6.01$ & $15.4 \pm 9.19$ & 0.1567 \\
\hline Hind limb & $6.2^{\mathrm{b}} \pm 2.19$ & $6.6^{\mathrm{b}} \pm 2.06$ & $4.4^{\mathrm{a}} \pm 2.10$ & 0.0021 \\
\hline Subcutaneous fat : Neck & $4.7^{\mathrm{b}} \pm 3.60$ & $3.4^{\mathrm{b}} \pm 3.14$ & $1.3^{\mathrm{a}} \pm 1.39$ & 0.0061 \\
\hline Fore limb & $3.7^{\mathrm{b}} \pm 1.86$ & $4.0^{\mathrm{b}} \pm 1.91$ & $2.5^{\mathrm{a}} \pm 1.80$ & 0.0272 \\
\hline Dorsal trunk & $5.8^{\mathrm{b}} \pm 4.00$ & $5.0^{\mathrm{b}} \pm 2.83$ & $3.2^{\mathrm{a}} \pm 1.80$ & 0.0163 \\
\hline Ventral trunk & $8.5^{b} \pm 5.22$ & $8.0^{b} \pm 5.62$ & $4.3^{\mathrm{a}} \pm 4.24$ & 0.0297 \\
\hline Hind limb & $3.6^{\mathrm{b}} \pm 2.38$ & $4.7^{\mathrm{C}} \pm 1.86$ & $2.2^{\mathrm{a}} \pm 1.13$ & $<0.0001$ \\
\hline
\end{tabular}

Means in the same row with different superscripts 'a', 'b' or 'c' differ significantly $(P<0.05)$.

Table 8 Effect of age on the joint proportions (\%) in the right carcass halves of South African indigenous goats (means \pm S.D.)

\begin{tabular}{|c|c|c|c|c|c|}
\hline \multirow{2}{*}{ Characteristic } & \multicolumn{4}{|c|}{ Age class } & \multirow{2}{*}{$P$-value } \\
\hline & 0 -teeth & 2-teeth & 4- to 6-teeth & 8-teeth & \\
\hline $\mathrm{N}$ & 16 & 32 & 20 & 20 & \\
\hline Neck & $12.6 \pm 1.60$ & $12.5 \pm 1.87$ & $12.2 \pm 1.56$ & $12.5 \pm 1.20$ & 0.8691 \\
\hline Fore limb & $18.8 \pm 1.35$ & $19.3 \pm 1.26$ & $19.2 \pm 1.12$ & $18.3 \pm 1.51$ & 0.0918 \\
\hline Dorsal trunk & $20.4 \pm 1.09$ & $21.0 \pm 1.27$ & $20.1 \pm 1.73$ & $21.3 \pm 1.61$ & 0.0771 \\
\hline Ventral trunk & $18.7^{\mathrm{b}} \pm 2.69$ & $17.1^{\mathrm{a}} \pm 1.71$ & $19.2^{\mathrm{b}} \pm 2.42$ & $19.6^{\mathrm{b}} \pm 2.94$ & 0.0047 \\
\hline Hind limb & $29.5^{\mathrm{ab}} \pm 1.63$ & $30.2^{b} \pm 2.20$ & $29.3^{\mathrm{ab}} \pm 1.10$ & $28.3 \mathrm{a} \pm 2.14$ & 0.0055 \\
\hline
\end{tabular}

Means in the same row with different superscripts ‘a' or 'b’ differ significantly $(\mathrm{P}<0.05)$.

The highest proportions of lean were in the 2-teeth and the 4- to 6-teeth groups $(P=0.008)$, which had about $64 \%$ lean (Table 9). The milk-teeth kids had the lowest proportion of about $62 \%$. The proportions of bone and subcutaneous fat were not significantly affected by the age of the goats $(P>0.05)$. However, 
Table 9 Effect of age on the proportions of dissectible tissues (\%) and meat yield indices of the right carcass halves of South African indigenous goats (means \pm S.D.)

\begin{tabular}{|c|c|c|c|c|c|}
\hline & \multicolumn{4}{|c|}{ Age class } & \multirow{2}{*}{$P$-value } \\
\hline & 0 -teeth & 2-teeth & 4- to 6-teeth & 8-teeth & \\
\hline $\mathrm{N}$ & 16 & 32 & 21 & 19 & \\
\hline Lean & $61.8^{\mathrm{a}} \pm 4.21$ & $64.7^{c} \pm 3.46$ & $63.9^{\mathrm{bc}} \pm 2.97$ & $62.1^{\mathrm{ab}} \pm 5.81$ & 0.0077 \\
\hline Bone & $22.2 \pm 3.38$ & $21.9 \pm 1.91$ & $21.1 \pm 3.02$ & $20.9 \pm 4.32$ & 0.4740 \\
\hline Intermuscular fat & $10.8^{\mathrm{bc}} \pm 4.45$ & $8.1^{\mathrm{a}} \pm 3.27$ & $9.6^{\mathrm{ab}} \pm 3.27$ & $11.9^{c} \pm 6.43$ & 0.0009 \\
\hline Subcutaneous fat & $4.3 \pm 2.32$ & $4.3 \pm 2.15$ & $4.5 \pm 1.96$ & $4.1 \pm 2.12$ & 0.9293 \\
\hline Total carcass fat & $15.2^{\mathrm{b}} \pm 6.54$ & $12.4^{\mathrm{a}} \pm 4.74$ & $14.1^{\mathrm{ab}} \pm 4.51$ & $16.1^{\mathrm{b}} \pm 8.25$ & 0.0266 \\
\hline Lean/bone & $2.8 \pm 0.38$ & $3.0 \pm 0.26$ & $3.1 \pm 0.36$ & $3.07 \pm 0.54$ & 0.2745 \\
\hline Lean-and-fat/bone & $3.6 \pm 0.70$ & $3.6 \pm 0.43$ & $3.8 \pm 0.53$ & $4.0 \pm 0.94$ & 0.5332 \\
\hline
\end{tabular}

Table 10 Effect of age on the proportions of the dissectible tissues (\%) within joints of the right carcass halves of South African indigenous goats (means \pm S.D.)

\begin{tabular}{|c|c|c|c|c|c|c|}
\hline & & \multicolumn{4}{|c|}{ Age class } & \multirow{2}{*}{$P$-value } \\
\hline & & 0-teeth & 2-teeth & 4- to 6-teeth & 8-teeth & \\
\hline \multicolumn{2}{|l|}{$\mathrm{N}$} & 16 & 32 & 20 & 20 & \\
\hline \multirow[t]{5}{*}{ Lean: } & Neck & $58.6 \pm 5.57$ & $60.9 \pm 6.64$ & $62.7 \pm 6.10$ & $63.2 \pm 7.66$ & 0.0667 \\
\hline & Fore limb & $63.2^{\mathrm{a}} \pm 3.68$ & $67.1^{\mathrm{b}} \pm 3.14$ & $66.5^{\mathrm{b}} \pm 3.32$ & $66.3^{\mathrm{b}} \pm 4.42$ & 0.0016 \\
\hline & Dorsal trunk & $56.8^{\mathrm{ab}} \pm 5.71$ & $60.5^{c} \pm 4.19$ & $59.1^{\mathrm{bc}} \pm 4.06$ & $55.8^{\mathrm{a}} \pm 7.67$ & 0.0064 \\
\hline & Ventral trunk & $58.3 \pm 7.94$ & $58.4 \pm 7.08$ & $59.4 \pm 6.47$ & $56.5 \pm 7.63$ & 0.5126 \\
\hline & Hind limb & $68.4 \pm 2.60$ & $71.4^{\mathrm{b}} \pm 2.77$ & $69.5^{\mathrm{ab}} \pm 2.74$ & $68.1^{\mathrm{a}} \pm 4.34$ & 0.0033 \\
\hline \multicolumn{2}{|c|}{ Bone: Neck } & $22.6 \pm 5.54$ & $22.0 \pm 4.01$ & $20.6 \pm 4.70$ & $20.2 \pm 4.80$ & 0.3801 \\
\hline & Fore limb & $23.7^{\mathrm{b}} \pm 3.37$ & $23.1^{\mathrm{b}} \pm 2.59$ & $21.0^{\mathrm{a}} \pm 3.19$ & $21.7^{\mathrm{ab}} \pm 4.06$ & 0.0366 \\
\hline & Dorsal trunk & $27.7 \pm 5.38$ & $26.5 \pm 3.50$ & $27.2 \pm 4.69$ & $26.4 \pm 6.11$ & 0.7956 \\
\hline & Ventral trunk & $15.5 \pm 3.78$ & $17.1 \pm 2.49$ & $16.4 \pm 5.23$ & $16.3 \pm 6.61$ & 0.7204 \\
\hline & Hind limb & $21.7 \pm 2.25$ & $20.7 \pm 1.87$ & $20.7 \pm 2.49$ & $20.1 \pm 2.98$ & 0.2773 \\
\hline \multicolumn{2}{|c|}{ Intermuscular fat: Neck } & $13.8 \pm 5.40$ & $12.0 \pm 5.16$ & $12.4 \pm 4.52$ & $14.7 \pm 9.64$ & 0.2269 \\
\hline & Fore limb & $8.6 \pm 4.77$ & $5.7 \pm 4.76$ & $7.8 \pm 4.12$ & $8.8 \pm 6.20$ & 0.0887 \\
\hline & Dorsal trunk & $9.0^{\mathrm{a}} \pm 3.74$ & $7.6^{\mathrm{a}} \pm 5.16$ & $8.1^{\mathrm{a}} \pm 3.04$ & $12.0^{\mathrm{b}} \pm 7.16$ & 0.0059 \\
\hline & Ventral trunk & $19.5^{\mathrm{b}} \pm 8.65$ & $14.6^{\mathrm{a}} \pm 7.00$ & $16.4^{\mathrm{ab}} \pm 5.98$ & $19.6^{\mathrm{b}} \pm 11.11$ & 0.0213 \\
\hline & Hind limb & $6.3^{\mathrm{b}} \pm 2.28$ & $4.5^{\mathrm{a}} \pm 1.79$ & $5.5^{\mathrm{ab}} \pm 2.34$ & $6.5^{\mathrm{b}} \pm 2.43$ & 0.0055 \\
\hline \multicolumn{2}{|c|}{ Subcutaneous fat: Neck } & $3.7 \pm 3.09$ & $4.2 \pm 3.91$ & $3.2 \pm 2.80$ & $1.3 \pm 2.40$ & 0.0723 \\
\hline & Fore limb & $3.8 \pm 1.94$ & $3.4 \pm 1.80$ & $3.9 \pm 2.17$ & $2.6 \pm 1.54$ & 0.1695 \\
\hline & Dorsal trunk & $5.3 \pm 4.39$ & $4.0 \pm 3.50$ & $5.1 \pm 1.78$ & $4.3 \pm 3.82$ & 0.4170 \\
\hline & Ventral trunk & $6.1 \pm 3.56$ & $8.9 \pm 5.48$ & $6.4 \pm 5.87$ & $6.3 \pm 4.71$ & 0.2826 \\
\hline & Hind limb & $3.0^{\mathrm{ab}} \pm 1.53$ & $2.5^{\mathrm{a}} \pm 2.10$ & $3.6^{\mathrm{bc}} \pm 1.39$ & $4.7^{c} \pm 2.84$ & 0.0015 \\
\hline
\end{tabular}

intermuscular and total carcass fat percentages tended to be lowest in the 2- to 6-teeth groups and highest in the 8-teeth group $(P<0.05)$. The indices lean/bone and lean-and-fat/bone did not vary with the age of the goats $(P>0.05)$. 
Within the fore limb, dorsal trunk and hind limb, the percentage of lean varied significantly $(P<0.01)$ with age of the goats (Table 10). As was the case within the entire right half carcasses (Table 8), the proportion of lean tended to be higher for the 2- to 6-teeth groups and lower for the milk-teeth and 8-teeth groups. Intermuscular fat percentages of the neck and fore limb did not vary $(P>0.05)$ with age. However, the dorsal trunks of the 8-teeth group had the highest $(P=0.006)$ percentage intermuscular fat. The mean intermuscular fat percentage in the 8-teeth group averaged 3.98\% units more than of the younger goats. In the ventral trunk and hind limb, the 2- to 6-teeth groups generally had lower intermuscular fat percentages than the milk- and 8-teeth groups $(P<0.05)$

Only the subcutaneous fat percentage of the hind limb was significantly affected by the age of the goats $(P=0.002)$. The proportion was lowest in the younger goats with up to 2-teeth (average of $2.75 \%)$ and increased to $4.74 \%$ in the 8 -teeth group.

The percentages of the neck and dorsal trunk were similar $(P>0.05)$ between the non- and preslaughter conditioned groups (Table 11). However, the fore and hind limb proportions were greater in the carcasses of the non-conditioned goats $(P<0.001)$, while the ventral trunk percentage was greater in the carcasses of the pre-slaughter conditioned goats $(P<0.0001)$.

Table 11 Effect of pre-slaughter conditioning on proportions of the joints (\%) in the right carcass halves of South African indigenous goats (means \pm S.D.)

\begin{tabular}{lccc}
\hline & \multicolumn{2}{c}{ Pre-slaughter conditioning } & \multirow{2}{*}{$P$-value } \\
\cline { 2 - 3 } & Non-conditioned & Pre-slaughter conditioned & \\
\hline $\mathrm{N}$ & 49 & 39 & \\
Neck & $11.9 \pm 1.39$ & $12.3 \pm 1.89$ & 0.7698 \\
Fore limb & $19.7 \pm 1.18$ & $18.3 \pm 1.25$ & 0.0008 \\
Dorsal trunk & $20.2 \pm 1.60$ & $21.4 \pm 1.30$ & 0.7081 \\
Ventral trunk & $17.5 \pm 2.43$ & $19.4 \pm 2.00$ & $<0.0001$ \\
Hind limb & $30.7 \pm 1.44$ & $28.7 \pm 1.94$ & 0.0004 \\
\hline
\end{tabular}

Table 12 Effect of pre-slaughter conditioning on proportions of the tissues (\%) and meat yield indices of the right carcass halves of South African indigenous goats (means \pm S.D.)

\begin{tabular}{lccc}
\hline \multirow{2}{*}{ Characteristic } & \multicolumn{2}{c}{ Pre-slaughter conditioning } & \multirow{2}{*}{$P$-value } \\
\cline { 2 - 3 } & Non-conditioned & Pre-slaughter conditioned & \\
\hline $\mathrm{N}$ & 49 & 39 & \\
Lean & $65.5 \pm 2.88$ & $59.9 \pm 4.26$ & $<0.0001$ \\
Bone & $23.5 \pm 3.08$ & $19.4 \pm 1.74$ & $<0.0001$ \\
Intermuscular fat & $6.8 \pm 3.11$ & $13.7 \pm 3.77$ & $<0.0001$ \\
Subcutaneous fat & $3.4 \pm 1.74$ & $6.0 \pm 1.96$ & $<0.0001$ \\
Total carcass fat & $10.2 \pm 4.33$ & $19.7 \pm 4.74$ & $<0.0001$ \\
Lean/bone & $2.8 \pm 0.39$ & $3.1 \pm 0.33$ & 0.0097 \\
Lean-and-fat/bone & $3.3 \pm 0.58$ & $4.1 \pm 0.48$ & $<0.0001$ \\
\hline
\end{tabular}

The lean and bone percentages were higher in the carcasses of the non-conditioned goats $(P<0.0001)$ while all carcass fat proportions were higher $(P<0.0001)$ in the carcasses of the goats that were 
conditioned prior to slaughter (Table 12). Consequently the indices, lean/bone and lean-and-fat/bone, were respectively $9 \%$ and $25 \%$ higher for the pre-slaughter conditioned than the non-conditioned group.

Within each joint, the lean and bone percentages were consistently higher $(P<0.05)$ in the nonconditioned goats (Table 13). Conversely, intermuscular fat percentages were consistently higher $(P<0.01)$ in the joints of the pre-slaughter conditioned goats. Subcutaneous fat percentage was not as variable as the other tissues. Only that of the dorsal trunk and the hind limb was increased $(P<0.0001)$ by pre-slaughter conditioning.

\section{Discussion}

The delineation of the age classes using dentition was in line with the current ruminant carcass grading system in South Africa, which defines classes A, AB, B and C as animals with milk teeth, one to two permanent incisors, three to six permanent incisors and more than six incisors, respectively (SAMIC, 2010). According to Horgan et al. (1988) and Singh \& Saini (1998), the first pair of permanent incisors erupts at 15 to 17 months, the second at 20 to 26 months, the third at 24 to 26 months and the fourth pair at 28 to 30 months in medium and large goats. Although the age range at which each set of permanent incisors erupts is very wide within and among the breeds, especially for the later sets (Horgan et al., 1988; Singh \& Saini, 1998), dentition serves as a guideline for the estimation of the age of goats raised by smallholder farmers, which would otherwise be impossible to estimate since the farmers do not keep such records. Moreover dentition is said to be a more precise estimation of physiological age than methods such as degree of ossification of cartilage or the appearance of some bones of thoracic and lumbar vertebrae (Price, 1982).

Table 13 Effect of pre-slaughter conditioning on proportions of dissectible tissues in the joints of the right carcass halves of South African indigenous goats (means \pm S.D.)

\begin{tabular}{|c|c|c|c|c|}
\hline & & \multicolumn{2}{|c|}{ Pre-slaughter conditioning } & \multirow{2}{*}{$P$-value } \\
\hline & & Non-conditioned & Pre-slaughter conditioned & \\
\hline \multicolumn{2}{|l|}{$\mathrm{N}$} & 49 & 39 & \\
\hline \multirow[t]{5}{*}{ Lean: I } & Neck & $63.1 \pm 5.32$ & $55.9 \pm 6.71$ & 0.0091 \\
\hline & Fore limb & $66.9 \pm 3.06$ & $64.0 \pm 3.96$ & 0.0018 \\
\hline & Dorsal trunk & $60.89 \pm 4.27$ & $54.7 \pm 5.93$ & 0.0014 \\
\hline & Ventral trunk & $63.0 \pm 5.93$ & $51.3 \pm 5.59$ & $<0.0001$ \\
\hline & Hind limb & $70.3 \pm 2.63$ & $68.6 \pm 3.75$ & 0.0227 \\
\hline \multirow[t]{5}{*}{ Bone: $N$} & Neck & $24.2 \pm 4.51$ & $19.6 \pm 3.62$ & 0.0009 \\
\hline & Fore limb & $23.9 \pm 3.38$ & $20.5 \pm 2.19$ & 0.0012 \\
\hline & Dorsal trunk & $29.8 \pm 4.74$ & $23.6 \pm 3.19$ & 0.0005 \\
\hline & Ventral trunk & $18.3 \pm 4.91$ & $14.2 \pm 2.97$ & 0.0023 \\
\hline & Hind limb & $21.8 \pm 2.52$ & $19.3 \pm 1.80$ & 0.0025 \\
\hline \multicolumn{2}{|c|}{ Intermuscular fat: Neck } & $8.3 \pm 4.40$ & $19.0 \pm 4.87$ & $<0.0001$ \\
\hline & Fore limb & $5.5 \pm 3.44$ & $10.6 \pm 5.52$ & 0.0005 \\
\hline & Dorsal trunk & $5.7 \pm 3.05$ & $13.3 \pm 5.58$ & $<0.0001$ \\
\hline & Ventral trunk & $11.2 \pm 6.04$ & $23.2 \pm 6.61$ & $<0.0001$ \\
\hline & Hind limb & $5.0 \pm 2.22$ & $6.6 \pm 1.99$ & 0.0051 \\
\hline \multicolumn{2}{|c|}{ Subcutaneous fat: Neck } & $3.4 \pm 3.11$ & $4.3 \pm 3.42$ & 0.5472 \\
\hline & Fore limb & $3.1 \pm 1.87$ & $4.1 \pm 1.77$ & 0.2226 \\
\hline & Dorsal trunk & $2.8 \pm 1.59$ & $7.1 \pm 3.79$ & $<0.0001$ \\
\hline & Ventral trunk & $6.4 \pm 5.00$ & $9.6 \pm 5.36$ & 0.2202 \\
\hline & Hind limb & $2.3 \pm 1.39$ & $4.7 \pm 2.34$ & $<0.0001$ \\
\hline
\end{tabular}


Live weight and chest girth have been used in several studies to define the size of small ruminants (e.g. Owen, 1975; Mukherjee et al., 1981; Mukherjee et al., 1986; Simela et al., 2000; Atta \& El Khidir, 2004). The live weight, chest girth and carcass measurements of the goats used in this study compare well to other breeds in the region, namely the Tswana goats of Botswana (Fisher et al., 1976; Owen \& Norman, 1977) and the Matebele goats of Zimbabwe (Simela et al., 2000), for example; the reported mean chest girth for castrated Matebele goats ranged from $59.8 \mathrm{~cm}$ to $83.3 \mathrm{~cm}$ between the milk- and 8-teeth stages (Simela et al., 2000). The average live weight of these castrates when they are marketed in the commercial sector ranged from a stipulated minimum of $25 \mathrm{~kg}$ (Hatendi, 1993) to about $41 \mathrm{~kg}$ at the 6-teeth stage (Simela et al., 2000). Side length of carcasses of mixed sex ranged from $57.0 \mathrm{~cm}$ at the milk-teeth stage to 66.2 at the 6to 8-teeth stage (Simela et al., 1999). The corresponding carcass weights were $12.5 \mathrm{~kg}, 13.3 \mathrm{~kg}, 16.3 \mathrm{~kg}$ and $19.7 \mathrm{~kg}$, respectively for the milk, 2-, 4- and 6- to 8-teeth groups (Simela et al., 1999).

The side length of Tswana castrated goats ranged from $55.3 \mathrm{~cm}$ at the milk-teeth stage to $64.4 \mathrm{~cm}$ at the 6-teeth stage (Owen \& Norman, 1977), respectively. The corresponding range of live weights was $24 \mathrm{~kg}$ to $41 \mathrm{~kg}$ and the carcass weights of the milk-, 2-, 4- and 6-teeth castrates were $9.89 \mathrm{~kg}, 11.69 \mathrm{~kg}$ and 13.87 $\mathrm{kg}$ and $17.67 \mathrm{~kg}$, respectively. Corresponding measurements in this study (Tables 2 - 4) are of similar magnitude with these reported values.

In essence the South African indigenous goats are of the same type as the large Bantu goats of southern Africa that have been described by Mason (1981), such as the Tswana goat and what is now termed the Matebele goats of Zimbabwe. They are large breeds compared to most others on the African continent (Simela \& Merkel, 2008). It is for this reason that many researchers are of the opinion that these breeds have a high potential for commercial chevon production.

The mean dressing out percentages varied between $38 \%$ and $44 \%$, which generally agrees with the values reported for various goat breeds worldwide (Devendra \& Owen, 1983, Kadim et al., 2004) as well as the large southern African goats (Owen \& Norman, 1977; Simela et al., 2000). For the latter breeds, Owen \& Norman (1977) obtained values ranging from $43.1 \%$ for milk-teeth kids to $48.3 \%$ for 8-teeth castrated Tswana goats. Eight-teeth females had a dressing percentage of 39.7\%. Simela et al. (2000) obtained values ranging from $42.3 \%$ to $46.8 \%$ for Matebele goats weighing from $25 \mathrm{~kg}$ to over $45 \mathrm{~kg}$. One abattoir that slaughtered goats in Zimbabwe used an estimation of about 42\% (Hatendi, 1993). Therefore, the dressing out percentages that were observed in the present study are in line with what is observed in commercial slaughter situations.

A large source of the variation in DO\% is the gut content which may account for as much as $26 \%$ of the live weight of the animal (Owen et al., 1983). Post-weaning gut content is particularly affected by the diet of the goats prior to slaughter. Gaili et al. (1972) noted that after 24 hours off feed but with access to water, unfattened goats averaged $18 \%$ gut content whereas those off a fattening diet averaged $8.8 \%$. The goats employed in the current study were weighed prior to feeding, 24 hours after the last feeding session in order to minimise differences in live weight due to gut content and obtain a dressing out percentage that is less biased by gut fill.

In addition to heavier carcasses and increased carcass fat, a higher plane of nutrition also typically results in a higher DO\% (Devendra \& Owen, 1983; Oman et al., 1999) as was observed herein. According to Hogg et al. (1992), fattened goats are expected to dress out 2 - 3\% more than those coming off pastures. Such a difference occurred between the non-conditioned and pre-slaughter conditioned groups of this study. Further to this, the intact males proved more productive in response to pre-slaughter conditioning in that the increase in their dressing out percentage and decrease in the chilling losses were greater than those of the castrates or females (Figure 1).

Chilling losses in this study averaged less than the 3\% that is usually estimated for chevon (Government of Zimbabwe, 1995). In Simela et al. (2000) such low chilling losses were associated with CCW of $16.9 \mathrm{~kg}$ and above. In this study the lower values may have been due to that the goats were generally in good condition at slaughter. However, when the goats were separated into non-condition and pre-slaughter conditioned groups, the advantages of improved nutrition were evident in the $30 \%$ difference in chilling losses between the non-condition and pre-slaughter conditioned groups.

The tissue distribution of the goat carcasses in this study averaged $63 \%$ lean, $22 \%$ bone, $10 \%$ intermuscular fat and 5\% subcutaneous fat. These values are within the ranges that have been reported for other goat breeds (Devendra \& Owen, 1983; Kirton, 1988; Simela et al., 1999). Low carcass fat is one of the main attractions to chevon. However, the low and rather invariable subcutaneous fat cover is a particular 
cause for concern in commercial chevon production since it is often well below the levels considered necessary for effective carcass chilling, without the risk of cold shortening (Smith et al., 1976; Dikeman, 1996). The low subcutaneous cover has also contributed to the downgrading of goat carcasses in a number of commercial enterprises, particularly where the classification/grading schedules that are employed are based on those of lamb and mutton (Pike et al., 1973; Simela et al., 1999). Several scientists (Devendra \& Owen, 1983; Kirton, 1988; Prasad \& Kirton, 1992; Simela et al., 1998) have emphasised this misconception and recommended use of classification systems that are indicative of the possible end use of the carcass rather than one that attempts to indicate an objective carcass quality. Such an approach would better cater for diverse consumer populations with different expectations, such as occurs in South Africa.

Typically, the intact males tended to yield leaner carcasses with less cavity fat than the females. Such a trend has been observed among cattle, whereby steers reportedly have $40 \%$ more omental and kidney fat, $71 \%$ more subcutaneous fat and 26\% more intermuscular fat than bulls (Brännäng, 1971). In this study the castrated and intact males differed significantly in carcass fat content. Castrates attained percentages of intermuscular and subcutaneous fat that were $41 \%$ and $91 \%$ greater than the respective percentages in the intact males. Pearson (1990) also discussed the differences in the proportion of the quarters within beef carcasses: bulls reportedly have some $2.5 \%$ more fore quarter than steers. Similar differences were obtained in this study when just the neck and hind limbs were compared; the intact males had about $2.4 \%$ units more neck and $1.5 \%$ units less hind limb than the castrates. Therefore, the tissue distributions of the goats were typical of the trends with the sexes.

The lean carcasses, coupled with the faster growth of the intact males (Louca et al., 1977; Allan \& Holst, 1989; Aregheore, 1995) are the basis for the drive to produce young intact males in preference to castrates and females. However, at sexual maturity and beyond, meat from intact males is believed to have an unacceptably strong odour caused by androgens (Norman, 1991), which leads to the downgrading of their carcasses.

No standards have been set for the presentation of chevon to consumers to date. However, in a chevon industry survey carried out in Zimbabwe, indications were that most consumers that purchase chevon from retail outlets prefer cuts and joints. Unfortunately that study did not delve further into the nature of the preferred cuts and joints. The general trend in commercial chevon production is to use cuts similar to that in lamb (Wilson, 1992). The effectiveness of this in marketing chevon is debatable since the two species differ in distribution of joints within the carcass as well as the dissectible tissues within the joints (Casey, 1982). In lamb the western-style high value cuts are associated with the loin region (dorsal trunk) and the hind limb. The composition of the hind limb of goats seems suitable for the production of high value cuts in that it has a low fat and high lean content. Although the dorsal trunk also has a low fat content, it tends to be bony. This is attested to by the high bone (27\%) and low lean content (58\%) of the cut as well as the relatively small LT areas, especially when compared to sheep (Riley et al., 1989), for example, the eye muscle area of a combined sample of young male and adult female goats averaged $7.9 \mathrm{~cm}^{2}$ while that for a similar sample of sheep averaged $11.3 \mathrm{~cm}^{2}$ (Riley et al., 1989). The implications of this are that the rib and loin cuts from goat carcasses would not be as meaty as similar cuts derived from the dorsal trunk of sheep.

An additional consideration in the jointing of goat carcasses is the classification of the cuts according to their perceived value to consumers. Previous research shows that the preference for the cuts varies with cultural backgrounds. Whereas in most of the western world, cuts from the hind limb and the dorsal region are of prime value and the breast region is of low value, a high preference for the breasts has been shown in some studies conducted in Africa and Asia (Wilson, 1992; Prasad \& Kirton, 1992). An understanding of the market needs within each country is therefore essential for the development of a market for chevon.

A previously reported phenomenon with unimproved goats is that there is little variation in the lean/bone index with sex and age (Simela et al., 1999). This phenomenon is in line with the fact that goats are relatively late maturing and hence age-related changes in the proportions of tissues do not occur until at a late stage (Owen et al., 1978). This has been demonstrated by the relatively high growth coefficients for lean, bone and fat, particularly when compared to those of sheep. Owen et al. (1978) reported Tswana goat lean, bone and fat growth coefficients of 1.170, 0.776 and 1.995, respectively. Corresponding values for Boer goats reported by Casey (1982) were 1.075, 0.769 and 1.988 whereas the average values for the sheep breeds were $0.911,0.696$ and 2.096 for lean, bone and fat, respectively. However, the meat yield indices, including the $m$. longissimus area, are increased by improved nutrition (Gaili et al., 1972; Mtenga \& Kitaly, 1990; Johnson \& McGowan, 1998; Oman et al., 1999). The increases would obviously be more evident and 
consequential in young growing animals than in old goats, and amongst the former, in intact males than in castrates and females (Louca et al., 1977; Allan \& Holst, 1989).

\section{Conclusion}

Indigenous goats of South Africa belong to the large breeds that are considered to have a high potential for chevon production. Within the goat carcasses, the hind limb seems most ideal for high lean, low fat, high value cuts. The dorsal trunk was bony and yielded less lean, which may not make it a high value cut in terms of saleable meat yield. Pre-slaughter conditioning improved the overall size of the goats. It also reduced the losses from the goats during slaughter and chilling. Although pre-slaughter conditioning reduced the percentage of lean and increased that of fat, it also improved the meat yield indices. The findings of this study imply a need for further research on carcass classification to meet consumer requirements and carcass handling that suits low fat carcasses.

\section{Acknowledgements}

The authors wish to thank the National Research Foundation (NRF, GUN 2053732), the South AfricaNetherlands Research Programme on Alternatives in Development (SANPAD) and the Third World Organisation for Women in Science, now Organization for Women in Science for the Developing World (OWSDW) for their financial support; the Meat Science Centre of the Agricultural Research Council, Irene for assistance with laboratory analyses and STATOMET at the University of Pretoria for the statistical analysis of the data.

\section{References}

Allan, C.J. \& Holst, P.J., 1989. Comparison of growth and dressing percent between intact male, castrated male and female kids of Australian bush goats. Small Rumin. Res. 2, 63-68.

Aregheore, E.M., 1995. Effect of sex on growth rate, voluntary food intake and nutrient digestibility of West African Dwarf goats fed crop residue rations. Small Rumin. Res. 15, 217-221.

Atta, M. \& El Khidir, O.A., 2004. Use of heart girth, wither height and scapuloischial length for prediction of live weight of Nilotic sheep. Small Rumin. Res. 55, 23-237.

Brännäng, E., 1971. Studies on monozygous cattle twins. XXIII. The effect of castration and age of castration on development of single muscles, bones and special sex characters. Part II. Swedish J. Agric. Res. 1, 69-78.

Casey, N.H., 1982. Carcass and growth characteristics of four South African sheep breed and the Boer goat. DSc (Agric) thesis, University of Pretoria, South Africa.

Chrystall, B.B., 1998. Meat quality - How well do we monitor and assure quality? Anim. Prod. Aust. 22, 47-52.

Devendra, C. \& Owen, J.E., 1983. Quantitative and qualitative aspects of meat production from goats. Wrld Anim. Rev. 47, 19-29.

Dikeman, M.E., 1996. The relationship of animal leanness to meat tenderness. Reciprocal Meat Conference Proc. 49, 87-101.

Fisher, A.V. \& de Boer, H., 1994. The EAAP Standard method of sheep carcass assessment. Carcass measurements and dissection procedures. Report of the EAAP Working group on carcass Evaluation in co-operation with CIHEAM. Instituto Agronomico Mediterranio of Zaragoza and the CEC Directorate General for Agriculture in Brussels. Livest. Prod. Sci. 38, 149-159.

Fisher, I.L., Frost, R.A., Owen, J.E. \& Norman, G.A., 1976. Studies on the meta production characteristics of Botswana goats and sheep. Meat Sci. 1, 63-85.

Gaili, E.S., Ghanem, Y.S. \& Mukhtar, A.M.S., 1972. A comparative study of some carcass characteristics of Sudan desert sheep and goats. Anim. Prod. 14, 351-357.

Government of Zimbabwe, 1995. Statutory Instrument 80, 1995 Cold Storage Commission (Livestock). Carcass Classification and Grading Regulations, Government Printers, Zimbabwe, 17 pp.

Hatendi, P.R., 1993. The effects of dietary energy and nitrogen content on growth, body and carcass composition of stall fed castrated indigenous Zimbabwean goats. DPhil. thesis, Department of Animal Science, University of Zimbabwe, Harare, Zimbabwe.

Hogg, B.W., Mercer, G.J.K., Mortimer, B.J., Kirton, A.H. \& Duganzich, D.M., 1992. Carcass and meat quality attributes of commercial goats in New Zealand. Small Rumin. Res. 8, 243-252. 
Horgan, D.J., King, N.L. \& Kurth, L.B., 1988. Methods for determining animal age. In: Proc. 34th Int. Congr. Meat Science and Technology, Brisbane, Australia. Part A. pp. 197-199.

Johnson, D.D. \& McGowan, C.H., 1998. Diet/management effects on carcass attributes and meat quality of young goats. Small Rumin. Res. 28, 93-98.

Kadim, I.T., Mahgoub, O., Al-Ajmi, D.S., Al-Maqbaly, R.S., Al-Saqri, N.M. \& Ritichie, A., 2004. An evaluation of the growth and carcass and meat quality characteristics of Omani goat breeds. Meat Sci. 66, 203-210.

Kirton, H., 1988. Characteristics of goat meat, including carcass quality and methods of slaughter. In: Goat Meat Production in Asia. Proceedings of a workshop held in Tando Jam, Pakistan, 13-18 March 1988. IDRC, Ottawa, Canada. pp. 87-99.

Louca, A., Economides, S. \& Hancock, J., 1977. Effects of castration on growth rate, feed conversion efficiency and carcass quality in Damascus goats. Anim. Prod. 24, 387-391.

Mason, I.L., 1981. Breeds. In: Goat Production. Ed. Gall, C., Academic Press Inc., London. pp. 59-110.

Mtenga, L.A. \& Kitaly, A.J., 1990. Growth performance and carcass characteristics of Tanzanian goats fed Chloris gayana hay with different levels of protein supplement. Small Rumin. Res. 3, 1-8.

Mukherjee, D.K., Singh, S.K. \& Mishra, H.R., 1981. Phenotypic correlations of body weight with body measurements in Grey Bengal goats. Indian J. Anim. Sci. 51, 682-694.

Mukherjee, D.K., Singh, C.S.P. \& Mishra, H.R., 1986. Body weight measurement relationships in Brown Bengal does. Indian J. Vet. Med. 10, 1004-1006.

Norman, G.A., 1991. The potential of meat from the goat. In: Developments in Meat Science. Volume 5. Ed. Lawrie, R.A., Elsevier Science Publishers Ltd. Essex, England. pp. 89-157.

Oman, J.S., Waldron, D.F., Griffin, D.B. \& Savell, J.W., 1999. Effect of breed type and feeding regimen on goat carcass traits. J. Anim. Sci. 77, 3215-3218.

Owen, J.E., 1975. The meat producing characteristics of the indigenous Malawi goat. Trop. Sci. 17, 123-138.

Owen, J.E. \& Norman, G.A., 1977. Studies on the meat production characteristics of Botswana goats and sheep: Part II: General body measurements, carcass composition and joint composition. Meat Sci. 1, 283-306.

Owen, J.E., Norman, G.A., Philbrooks, C.A. \& Jones, N.S.D., 1978. Studies on the meat production characteristics of Botswana goats and sheep. Part III: Carcass tissue composition and distribution. Meat Sci. 2, 59-74.

Owen, J.E., Arias Cereceres, M.T., Garcia Macias, J.A. \& Nunez Gonzalez, F.A., 1983. Studies on the Criolli goat of Northern Mexico. Part I: The effects of body weight on body components and carcass development. Meat Sci. 9, 191-204.

Pearson, A.M., 1990. Muscle growth and exercise. Crit. Rev. Food Sci. 29, 167-196.

Pike, M.I., Smith, G.C., Carpenter, Z.L. \& Shelton, M., 1973. Effects of maturity and fatness on the palatability of goat meat. J. Anim. Sci. 37, 269 (Abstr. 158).

Prasad, V.S.S. \& Kirton, A.H., 1992. Evaluation and classification of live goats and their carcasses and cuts. In: The Fifth International Conference on Goats, New Dehli, India. pp. 440-449.

Price, M.A., 1982. Meat carcass grading in the future. Can. J. Anim. Sci. 62, 3-13.

Riley, R.R., Savell, J.W., Johnson, D.D., Smith, G.C. \& Shelton, M., 1989. Carcass grades, rack composition and tenderness of sheep and goats as influenced by market class and breed. Small Rumin. Res. 2, 273-280.

SAMIC, 2010. Red Meat Classification in South Africa. Accessed in March 2010. Available at: http://www.samic.co.za/downloads/Redmeat.pdf.

Simela, L. \& Merkel, R., 2008. The contribution of chevon from Africa to global meat production. Meat Sci. 80, 101-109.

Simela, L., Ndlovu, L.R. \& Sibanda, L.M., 1998. Grading of goat carcasses in Zimbabwe and implications for communal area producers. BSAS/KARI Proceedings of an International Conference on Food, Lands and Livelihoods: Setting Research Agendas for Animal Science, 1998. BSAS, Edinburgh. pp. 7-8.

Simela, L, Ndlovu, L.R. \& Sibanda, L.M., 1999. Carcass characteristics of marketed Matebele goats from south-western Zimbabwe. Small Rumin. Res. 32, 173-179.

Simela, L., Gumede, S., Ndlovu, L.R. \& Sibanda, L.M., 2000. Handling losses of Matebele goats marketed through a commercial abattoir. In: Improvement of market orientated small ruminant production 
systems and sustainable land use in semi-arid regions of Southern Africa. Project TS3*-CT94-0312 Final Technical Report. pp. 147-156.

Simela, L., Webb, E.C. \& Frylinck, L., 2004. Post-mortem metabolic status, pH and temperature of chevon from indigenous South African goats slaughtered under commercial conditions. S. Afr. J. Anim. Sci. 34 (Suppl. 1), 204-207.

Singh, K. \& Saini, A.L., 1998. Dentition and ageing in Indian goats. In: Proc. 6th Int. Goat Conference, Beijing, China. pp. 153-159.

Smith, G.C., Dutson, T.R., Hostetler, R.L. \& Carpenter, Z.L., 1976. Fatness, rate of chilling and tenderness of lamb. J. Food Sci. 41, 748-755.

Wilson, R.T., 1992. Goat meat production and research in Africa and Latin America. In: Proc. $5^{\text {th }}$ Int. Goat Conference, New Dehli, India. pp. 458-472. 